\title{
Parasitic contamination of urban and rural environments in the Slovak Republic: dog's excrements as a source
}

\author{
I. PAPAJOVÁ ${ }^{1 *}$, J. PIPIKOVÁ ${ }^{1}$, J. PAPAJ ${ }^{2}$, A. ČIŽMÁR ${ }^{2}$ \\ ${ }^{1}$ Institute of Parasitology SAS, Hlinkova 3, 04001 Košice, Slovak Republic, ${ }^{*}$ E-mail: papaj@saske.sk; \\ ${ }^{2}$ Technical University of Košice, Letná 9, 04200 Košice, Slovak Republic
}

\begin{abstract}
Summary
The objective of this study was to determine the possibility of soil contamination with propagative stages of intestinal endoparasites at different public places (public parks, playgrounds, sandpits, sidewalks, road sides). In a oneyear-study, totally 578 dog's faecal samples from 8 towns (Košice, Trebišov, Vel'ké Kapušany, Prešov, Snina, Levoča, Zvolen and Trenčín) and 3 villages (Dlhé Stráže, Dravce, Valaliky) were examined for the presence of parasitic germs. $29.9 \%$ of faecal samples were positive. Eight different species of intestinal parasites with following incidence were detected: Toxocara canis (11.9\%), Trichuris vulpis (8.5\%), Ancylostomatidae (8.1\%), Taenia spp. (4.0\%), Toxascaris leonina (3.1\%), Capillaria spp. $(1.0 \%)$, Dipylidium caninum $(0.2 \%)$ and Coccidia oocysts $(0.2 \%)$. Additionally 285 sandpits were examined. Sand samples were collected from Košice (136), Zvolen (38), Trenčín (36), Prešov (30), Velké Kapušany (24), Snina (15), and village Valaliky (6). The parasitic eggs occurence in the sandpits was as follows: Toxocara spp. (11.8\%), Ancylostomatidae $(1.1 \%)$, Taenia type $(0.7 \%)$ and Trichuris spp. $(0.4 \%)$. The occurrence of Toxocara spp. varied between the urban and rural environments. The highest number of Toxocara spp. was found in village Valaliky $(33.3 \%)$ whereas cities showed lesser prevalence (Prešov - $10 \%$, Košice $-7.4 \%$, Trenčín $-5.6 \%$, Zvolen $5.3 \%$, Vel'ké Kapušany $-4.2 \%$ ). The epidemiological aspects and health risk factors are also discussed.
\end{abstract}

Keywords: endoparasites; T. canis; eggs; dog's excrements; sandpits

\section{Introduction}

Recently we have regularly come across the question of zoonoses prevention and eradication at all levels of society. This interferes with problems associated with animal (veterinary care) and public health (human health, safety of food chain), what subsequently directly or indirectly influences the economy of individual countries.

The source of parasitic zoonoses could be an animal, but also man in the body of which the agent of infection parasite occurs and is able to multiply and spread. Parasites, at various pathogenic stages, invade the hosts by various ways and are fully adapted for the parasitism.

Concerning the spread of parasitic zoonoses dogs are of great importance. Infection and way of transmission of the disease depends on the dog's life style and the environment in which the dog lives. An important factor of the risk for infection transmission is also possibility of animal to move outside its housing (backyards, open nature), or by the use of dogs for hunting or as a social companion. The transmission of parasitic diseases is accomplished through the environment contaminated with developmental stages (oo/cysts, larvae) of endoparasites (Papajová \& Juriš, 2012). Dogs and cats faeces infected with the germs of parasitic zoonoses are spread into the environment (cysts of intestinal parasitic protozoa - Entamoeba histolytica, Giardia spp., Toxoplasma gondii, the eggs of tapeworms - Dipylidium sp., Echinococcus sp., parasitic nematodes). These germs are able to cause parasitic infections not only in the specific hosts, but also in non-specific, i.e. in man. Regarding public health helminthozoonoses caused by Toxocara sp. and Toxascaris leonina dogs and cats are very important. For example, human toxocariasis occurs after ingestion of infective and the subsequent migration of larvae (Ondriska et al., 2013). Although the clinical features vary, three syndromes are recognized: toxocaral visceral larva migrans, ocular larva migrans and covert toxocariasis (Kinčeková et al., 1998, 1999, 2000; Sudhakar et al., 2013).

Dog's ownership in cities as well as in the countryside creates continuing problem and increasing risk. Contamination of environment with infectious stages of zoonoses in excrements originating from dogs and cats is related to this phenomenon (Sudhakar et al., 2013). The probability 


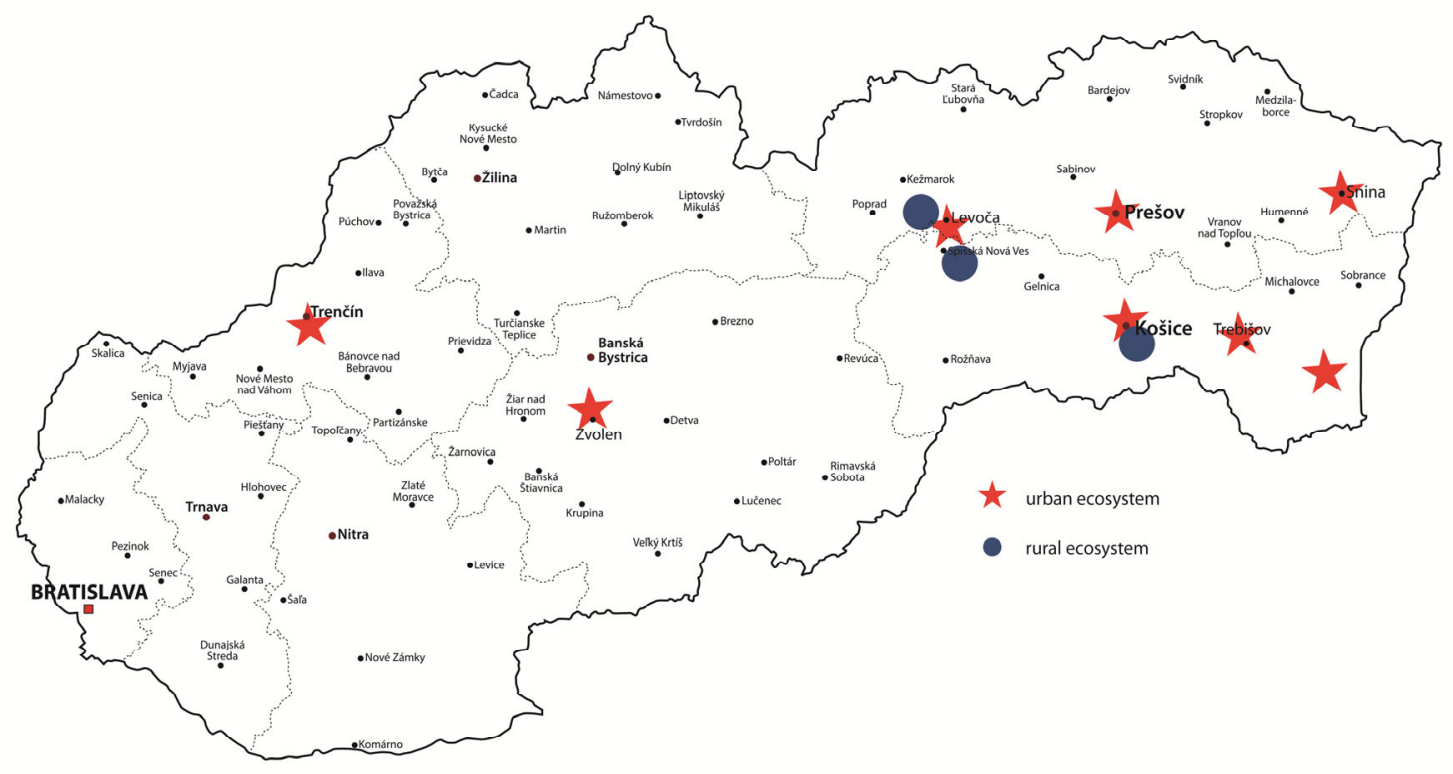

Fig. 1. Studied localities

of disease outbreak is higher in stray animals and in animals that are not under appropriate veterinary supervision. The problem of large towns is in a high density of dog's faeces and subsequent high environmental burden. Dog's excrements in the grass, public parks, playgrounds, sandpits, sidewalks, road sides present not only aesthetic problems, but it is also the problem of hygiene and epidemiology. In the Slovak Republic, up to $70 \%$ of dogs faeces are found in lawns with the dwelling houses nearby (Papajová et al., 2008). It is well known, that in contrast to the other biological pathogens, endoparasitic germs are highly resistant to the outdoor environment and can survive for a long time. Endoparasitic germs represent an increased risk factor for animals and also for the human population. For example, helminthological survey of contamination level in public parks, sandpits and children playgrounds showed the presence of Toxocara spp. eggs in more than $30 \%$ of samples (Oge \& Oge, 2000; Ruiz de Ybánẽz et al., 2001; Habluetzel et al., 2003). Seemingly low contamination of environment is not a result of low toxocariasis prevalence in dogs and cats, but the fact, that the animals are allowed to move within large unlimited area (Juriš et al. 1991).

The objectives of this study were to determine the incidence of parasites in dog's faecal samples and monitor the level of soil contamination with propagative stages of intestinal endoparasites at the different public places which are of public health importance (public parks, playgrounds, sandpits, sidewalks, road sides) in the Slovak Republic.

\section{Material and methods}

\section{Characterization of studied localities}

Košice $\left(48^{\circ} 43^{\prime} 12^{\prime \prime} \mathrm{N}, 21^{\circ} 15^{\prime} 29^{\prime \prime} \mathrm{E}\right)$ is the second largest city in the Slovak Republic and the biggest city in Eastern Slovakia. City is situated near the border with Hungary. Its population is approximately 240000 . Valaliky $\left(48^{\circ} 38^{\prime} 32.28^{\prime \prime} \mathrm{N}, 21^{\circ} 17^{\prime} 30.84^{\prime \prime} \mathrm{E}\right)$ is a small village located near Košice. Trebišov and Vel'ké Kapušany are 274 located in the Košice Region. Trebišov $\left(48^{\circ} 38^{\prime} 1^{\prime \prime} \mathrm{N}\right.$, $\left.21^{\circ} 43^{\prime} 2^{\prime \prime} \mathrm{E}\right)$ is a small industrial town, with a population around 23000 . Vel'ké Kapušany (48 33' 12" N, 22 $2^{\circ} 4^{\prime} 38^{\prime \prime}$ E) is a small town on the eastern plains of Slovakia. The population is about 9400 . Prešov $\left(49^{\circ} 0^{\prime} 0^{\prime \prime} \mathrm{N}\right.$, $\left.21^{\circ} 14^{\prime} 0^{\prime \prime} \mathrm{E}\right)$ is the third-largest city in the Slovak Republic. City population is approximately 91000 . Snina and Levoča are located in the Prešov Region. Snina $\left(48^{\circ} 59^{\prime} 17^{\prime \prime} \mathrm{N}, 22^{\circ} 9^{\prime} 24^{\prime \prime} \mathrm{E}\right)$ and Levoča $\left(49^{\circ} 1^{\prime} 16^{\prime \prime} \mathrm{N}\right.$, $\left.20^{\circ} 35^{\prime} 28^{\prime \prime} \mathrm{E}\right)$ are located on the north-eastern Slovakia. Dlhé Stráže $\left(49^{\circ} 1^{\prime} 33.24^{\prime \prime} \mathrm{N}, 20^{\circ} 31^{\prime} 16.32^{\prime \prime} \mathrm{E}\right)$ is village located in the district of Levoča where the majority the population is of the Roma nationality. The village Dravce $\left(49^{\circ} 1^{\prime} 0^{\prime \prime} \mathrm{N}, 20^{\circ} 29^{\prime} 0^{\prime \prime} \mathrm{E}\right)$ is located in the district of Levoča. It is inhabited by 781 people, of which 168 are of Roma ethnicity. Zvolen ( $48^{\circ} 34^{\prime} 42^{\prime \prime} \mathrm{N}, 19^{\circ} 7^{\prime} 24^{\prime \prime}$ E) with population of 43000 is a town in central Slovakia. Trenčín $\left(48^{\circ} 53^{\prime} 31^{\prime \prime} \mathrm{N}, 18^{\circ} 2^{\prime} 12^{\prime \prime} \mathrm{E}\right)$ is located in western part of Slovakia near border with Czech Republic. The city population is approximately 43000 . All demographic data are from Statistical Yearbook of the Slovak Republic 2013. Localities are shown on Figure 1.

\section{Copromicroscopical examination}

A total of 578 faecal samples of unknown dogs were collected randomly from the different public places which are of public health importance (public parks, playgrounds, sandpits, sidewalks, road sides) in the Slovak Republic. Dog's faecal samples were divided into two groups according to their collection point - urban or rural ecosystems. 508 samples of dog's excrements were examined from 8 towns (Košice - 158, Trebišov - 64, Vel'ké Kapušany -31 , Prešov -100 , Snina -23 , Levoča -58 , Zvolen - 32, Trenčín - 42) and 3 villages (Valaliky - 37, Dlhé Stráže - 17, Dravce - 16). Following the collection, faecal samples were stored at $4{ }^{\circ} \mathrm{C}$ and examined for the presence of propagative stages of endoparasites. A flotation method with the Shaeter's flotation solution (specific 
Table 1. Average prevalence in propagative stages of parasites in dog's excrements from urban and rural ecosystems

\begin{tabular}{ccc}
\hline & $\mathbf{n} / \mathbf{p}$ & $\mathbf{\%}$ \\
\hline urban & $508 / 151$ & 29.7 \\
rural & $70 / 22$ & 31.4 \\
\hline Total & $578 / 173$ & 29.9 \\
\hline $\mathrm{n}-$ number of examined samples, \\
$\mathrm{p}-$ number of positive samples
\end{tabular}

gravity $1.3 \mathrm{~g} . \mathrm{ml}^{-1}$ ) was used for copromicroscopical examination. A total of 3 grams of faecal sample were centrifuged with the water for 5 minutes at $1200 \mathrm{rpm}$. After pouring out the supernatant the Shaeter's flotation solution was poured into the test tube with the sediment, than stirred and centrifuged once again. After 5 minutes, the test tube was replenished with flotation solution (until a meniscus formed) and covered with cover glass. The cover glass was removed and put on the mount glass after an hour of egg flotation. For the detection of Giardia cysts the Faust flotation solution (specific gravity $1.18 \mathrm{~g} \cdot \mathrm{ml}^{-1}$ ) was used for each faecal sample. Samples were examined under the light microscope with 20x and 40x magnification (Leica, Germany).

\section{Parasitological examination of sand samples}

Sand samples were collected from 285 children sandpits in order to identify the presence of parasite eggs in the environment. We examined 136 sandpits from Košice, 6 from Valaliky, 24 from Vel'ké Kapušany, 30 from Prešov, 15 from Snina, 36 from Trenčín and 38 from Zvolen. The sandpits were classified as fenced and unfenced. The sand samples were investigated according to Kazacos (1983). To $100 \mathrm{~g}$ of pooled sand samples, $100 \mathrm{ml}$ of water and 0.5 $\mathrm{ml}$ of the Tween 40 was added and decanted for 10 minutes. Then the samples were sieved and replenished with $1000 \mathrm{ml}$ of water. After an hour of sedimentation, sand samples were centrifuged and then floated with Sheather's flotation solution (specific gravity 1.3 g. $\mathrm{ml}^{-1}$ ). Samples were examined under the light microscope with 20x and 40x magnification (Leica, Germany).

\section{Statistical methods}

The data were analyzed and tested for statistical significance using paired and unpaired $t$-tests and analysis of variance (ANOVA) was applied where more than two groups were compared. Results were considered significantly different when $p<0.05$ (STATISTICA 6.0 program Statsoft, USA). Differences in prevalence between urban or rural groups were considered significant at $\mathrm{p}<0.05$.

\section{Results}

A total of 578 dog's faecal samples were examined and $173(29.9 \%)$ were found to be positive for the presence of the propagative stages of endoparasites (Table 1). In all examined samples 8 different species of intestinal parasites were detected. Particularly Toxocara canis (11.9\%), Trichuris vulpis $(8.5 \%)$, eggs from the family Ancylostomatidae $(8.1 \%)$, Taenia type eggs $(4.0 \%)$, Toxascaris leonina (3.1\%), Capillaria spp. (1.0\%), Dipylidium caninum $(0.2 \%)$ and coccidia oocysts $(0.2 \%)$ were present and no Giardia positive samples were detected. We did not detect any differences in egg presence between the urban and rural environments. No significant association was also observed between the prevalence of endoparasitic eggs in the faeces from urban and rural ecosystems. 508 dog's faecal samples were collected from urban places in 8 towns and $151(29.7 \%)$. were found positive for the presence of parasite germs. The occurrence of parasitic species in the excrements from the public places in selected towns is summarised in Table 2. In Košice, out of 158 examined excrements, $24.1 \%$ samples were positive and the most prevalent parasite was $T$. canis $(13.3 \%)$. Higher prevalence of endoparasite was found in towns Trebišov $(57.8 \%)$ and Vel'ké Kapušany $(61.3 \%)$ which are located in Košice Region. In dog's faecal samples collected randomly from public areas in Trebišov the most frequent parasite were $T$. vulpis $(32.8 \%)$, then $T$. canis $(28.1 \%)$ and Ancylostamatidae $(22.0 \%)$. The most abundant parasitic species in dog's excrements from Vel'ké Kapušany were Ancylostomatidae (45.2\%) and T. canis $(41.9 \%)$. The least prevalence was detected in Capillaria spp. (Table 2). The highest prevalence of intestinal parasites in dog's faeces from public areas in Prešov Region was in the city Snina $(39.1 \%)$. The most prevalent were Ancylostomatidae (21.8\%) and T. canis $(17.4 \%)$. In

Table 2. Occurrence of dog's endoparasites in excrements from the public places in selected urban areas in the Slovak Republic

\begin{tabular}{|c|c|c|c|c|c|c|c|c|}
\hline & $\begin{array}{c}\text { Košice } \\
\text { (n-158) } \\
\%(p) \\
\end{array}$ & $\begin{array}{c}\text { Trebišov } \\
\text { (n-64) } \\
\%(p) \\
\end{array}$ & $\begin{array}{c}\text { Vel'ké Kapušany } \\
(\mathrm{n}-31) \\
\%(\mathrm{p}) \\
\end{array}$ & $\begin{array}{c}\text { Prešov } \\
(\mathrm{n}-100) \\
\%(\mathrm{p}) \\
\end{array}$ & $\begin{array}{l}\text { Snina } \\
(\mathrm{n}-23) \\
\%(\mathrm{p})\end{array}$ & $\begin{array}{l}\text { Levoča } \\
\text { (n-58) } \\
\%(p) \\
\end{array}$ & $\begin{array}{l}\text { Zvolen } \\
(\mathrm{n}-32) \\
\%(\mathrm{p}) \\
\end{array}$ & $\begin{array}{c}\text { Trenčín } \\
(n-42) \\
\%(p) \\
\end{array}$ \\
\hline Toxocara canis & $13.3(21)$ & $28.1(18)$ & $41.9(13)$ & $10.0(10)$ & $17.4(4)$ & $3.5(2)$ & $3.1(1)$ & $2.4(1)$ \\
\hline Toxascaris leonina & $2.5(4)$ & $7.8(5)$ & $25.8(8)$ & $3.0(3)$ & $0.0(0)$ & $1.7(1)$ & $0.0(0)$ & $0.0(0)$ \\
\hline Trichuris vulpis & $7.0(11)$ & $32.8(21)$ & $32.3(10)$ & $2.0(2)$ & $0.0(0)$ & $1.7(1)$ & $6.3(2)$ & $9.5(4)$ \\
\hline family Ancylostomatidae & $2.5(4)$ & $22.0(14)$ & $45.2(14)$ & $5.0(5)$ & $21.8(5)$ & $3.5(2)$ & $0.0(0)$ & $4.8(2)$ \\
\hline Capillaria spp. & $0.0(0)$ & $0.0(0)$ & $19.4(6)$ & $0.0(0)$ & $0.0(0)$ & $0.0(0)$ & $0.0(0)$ & $0.0(0)$ \\
\hline Dipilidium caninum & $0.0(0)$ & $0.0(0)$ & $0.0(0)$ & $0.0(0)$ & $0.0(0)$ & $1.7(1)$ & $0.0(0)$ & $0.0(0)$ \\
\hline family Taeniidae & $0.0(0)$ & $0.0(0)$ & $0.0(0)$ & $0.0(0)$ & $0.0(0)$ & $24.1(14)$ & $0.0(0)$ & $2.4(1)$ \\
\hline coccidia oocysts & $0.0(0)$ & $0.0(0)$ & $0.0(0)$ & $0.0(10)$ & $0.0(0)$ & $0.0(0)$ & $0.0(0)$ & $2.4(1)$ \\
\hline Total prevalence & $24.1(38)$ & $57.8(37)$ & $61.3(19)$ & $18.0(18)$ & $39.1(9)$ & $32.8(19)$ & $6.3(2)$ & $21.4(9)$ \\
\hline
\end{tabular}

$\mathrm{n}$ - number of examined samples, $\mathrm{p}$ - number of positive samples 
Table 3. Occurrence of dog's endoparasites in excrements from the public places in selected rural areas in the Slovak Republic

\begin{tabular}{|c|c|c|c|}
\hline & $\begin{array}{c}\text { Valaliky } \\
\text { (n-37) } \\
\%(p) \\
\end{array}$ & $\begin{array}{c}\text { Dlhé Stráže } \\
\text { (n-17) } \\
\%(p)\end{array}$ & $\begin{array}{c}\text { Dravce } \\
\text { (n-16) } \\
\% \text { (p) }\end{array}$ \\
\hline Toxocara canis & $18.9(7)$ & $11.8(2)$ & $0.0(0)$ \\
\hline Toxascaris leonina & $0.0(0)$ & $0.0(0)$ & $0.0(0)$ \\
\hline Trichuris vulpis & $0.0(0)$ & $0.0(0)$ & $0.0(0)$ \\
\hline family Ancylostomatidae & $16.2(6)$ & $0.0(0)$ & $0.0(0)$ \\
\hline Capillaria spp. & $0.0(0)$ & $0.0(0)$ & $0.0(0)$ \\
\hline Dipilidium caninum & $0.0(0)$ & $0.0(0)$ & $0.0(0)$ \\
\hline family Taeniidae & $0.0(0)$ & $29.4(5)$ & $18.8(3)$ \\
\hline coccidia oocysts & $0.0(0)$ & $0.0(0)$ & $0.0(0)$ \\
\hline Total prevalence & $32.4(12)$ & $41.2(7)$ & $18.8(3)$ \\
\hline
\end{tabular}

Prešov, T. canis was found as a primary parasite $(10.0 \%)$, followed by Ancylostomatidae (5.0\%), T. leonina (3.0\%) and T. vulpis. $(2.0 \%)$. The highest occurrence of Taeniidae $(24.1 \%)$ was found in samples from Levoča. $T$. canis were detected only in $3.5 \%$ out of the 58 examined samples from Levoča. Eggs of T. canis, T. vulpis, coccidia cysts, Ancylostomatidae and Taeniidae occurred occasionally in faeces collected from Zvolen and Trenčín (Table 2).

In rural areas only 70 dog's excrements were examined and 3 different parasites (Taeniidae, T. canis and Ancylostomatidae) were detected (Table 3). Due to the limited number of investigated samples, results could not be statistically evaluated.

Out of 285 sandpits, parasite were detected/present in 27 in unfenced sandpits from village Valaliky. In Vel'ké Kapušany Ancylostomatidae, Toxocara spp. and T. vulpis were present in 5 positive sandpits. The eggs of Toxocara spp. and Ancylostomatidae were recovered in sandpits from Prešov. Toxocara spp. and Taeniidae were found in soil samples from sandpits in Zvolen. As shown in Table 5, only Toxocara spp. were found in sandpits from Trenčín. In Snina, no eggs were found in any of the examined sandpits.

\section{Discussion}

The increasing densities of dog populations in urban and rural areas and close relationship of man with their pets is

Table 4. Presence of endoparasites in fenced and unfenced sandpits in the Slovak Republic

\begin{tabular}{cccccccc}
\hline & $\begin{array}{c}\text { Košice } \\
\mathbf{\%}(\mathbf{n} / \mathbf{p})\end{array}$ & $\begin{array}{c}\text { Valaliky } \\
\mathbf{\%}(\mathbf{n} / \mathbf{p})\end{array}$ & $\begin{array}{c}\text { Vel'ké Kapušany } \\
\mathbf{\%}(\mathbf{n} / \mathbf{p})\end{array}$ & $\begin{array}{c}\text { Prešov } \\
\mathbf{\%}(\mathbf{n} / \mathbf{p})\end{array}$ & $\begin{array}{c}\text { Snina } \\
\mathbf{\%}(\mathbf{n} / \mathbf{p})\end{array}$ & $\begin{array}{c}\text { Trenčín } \\
\mathbf{\%}(\mathbf{n} / \mathbf{p})\end{array}$ & $\begin{array}{c}\text { Zvolen } \\
\mathbf{\%}(\mathbf{n} / \mathbf{p})\end{array}$ \\
\hline fenced & $0.0(50 / 0)$ & $0.0(4 / 0)$ & $0.0(9 / 0)$ & $0.0(0 / 0)$ & $0.0(5 / 0)$ & $16.7(6 / 1)$ & $0.0(3 / 0)$ \\
unfenced $^{*}$ & $11.6(86 / 10)$ & $100.0(2 / 2)$ & $33.3(15 / 5)$ & $13.3(30 / 4)$ & $0.0(10 / 0)$ & $3.3(30 / 1)$ & $11.4(35 / 4)$ \\
\hline total & $7.4(136 / 10)$ & $33.3(6 / 2)$ & $20.8(24 / 5)$ & $13.3(30 / 4)$ & $0.0(15 / 0)$ & $5.6(36 / 2)$ & $10.5(38 / 4)$ \\
\hline n - number of examined samples, $\mathrm{p}-$ number of positive samples. * level of significance $\mathrm{p}<0.05$ & &
\end{tabular}

$(9.5 \%)$ of them. The unfenced sandpits were found to be significantly more contaminated than fenced sandpits. In unfenced sandpits $12.5 \%$ prevalence of the parasites were recorded, compared with fenced sandpits where only $1.3 \%$ positivity was observed (Table 4).

In Košice, out of 136 examined sandpits 10 (7.4\%) were positive for Toxocara spp. Only Toxocara spp. was found beneficial to the human beings (Macpherson, 2013; Overgaauw \& Knapen, 2013). Besides those benefits, the presence of large populations of untreated animals or stray dogs and cats establish a permanent reservoir for the infection. Contamination of the environment with parasitic germs is potential source of infection to the humans and other paratenic hosts (Despomier, 2003; Szabová et al.,

Table 5. Occurrence of endoparasites in sandpits from the selected towns and villages in the Slovak Republic

\begin{tabular}{|c|c|c|c|c|c|c|c|}
\hline & $\begin{array}{c}\text { Košice } \\
\text { (n-136) } \\
\% \text { (p) }\end{array}$ & $\begin{array}{c}\text { Valaliky } \\
\text { (n-6) } \\
\% \text { (p) } \\
\end{array}$ & $\begin{array}{c}\text { Vel'ké Kapušany } \\
(\mathbf{n}-24) \\
\%(p) \\
\end{array}$ & $\begin{array}{l}\text { Prešov } \\
(\mathbf{n}-30) \\
\%(p) \\
\end{array}$ & $\begin{array}{c}\text { Snina } \\
(n-15) \\
\%(n / p)\end{array}$ & $\begin{array}{c}\text { Trenčín } \\
\text { (n-36) } \\
\% \text { (p) }\end{array}$ & 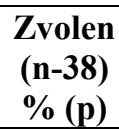 \\
\hline Toxocara spp. & $7.4(10)$ & $33.3(2)$ & $4.2(1)$ & $10.0(3)$ & $0.0(0)$ & $5.6(2)$ & $5.3(2)$ \\
\hline Toxascaris leonina & $0.0(0)$ & $0.0(0)$ & $0.0(0)$ & $0.0(0)$ & $0.0(0)$ & $0.0(0)$ & $0.0(0)$ \\
\hline Trichuris vulpis & $0.0(0)$ & $0.0(0)$ & $4.2(1)$ & $0.0(0)$ & $0.0(0)$ & $0.0(0)$ & $0.0(0)$ \\
\hline family Ancylostomatidae & $0.0(0)$ & $0.0(0)$ & $12.5(3)$ & $6.7(2)$ & $0.0(0)$ & $0.0(0)$ & $0.0(0)$ \\
\hline family Taeniidae & $0.0(0)$ & $0.0(0)$ & $0.0(0)$ & $0.0(0)$ & $0.0(0)$ & $0.0(0)$ & $5.3(2)$ \\
\hline coccidia oocysts & $0.0(10)$ & $0.0(0)$ & $0.0(0)$ & $0.0(0)$ & $0.0(0)$ & $0.0(0)$ & $0.0(0)$ \\
\hline Total prevalence & $7.4(10)$ & $33.3(2)$ & $20.8(5)$ & $13.3(4)$ & $0.0(0)$ & $5.6(2)$ & $10.5(4)$ \\
\hline
\end{tabular}

$\mathrm{n}$ - number of examined samples, $\mathrm{p}$ - number of positive samples 
2007; Macpherson, 2013; Ondriska et al., 2013; Khademvatan et. al., 2014).

Dogs and cats as definitive or intermediate hosts are associated with more than 60 zoonotic parasites. Considering their potential to transmit zoonoses animals pose a serious zoonotic risk through the contamination of environment with parasite eggs and oo/cysts in excrements (Schär et al., 2014). Since pet and stray animals have free access to the public places, they potentially serve as a source of contamination. Pets are brought to such public places and contaminate the soil with their excrements. The present study was carried out to determine the presence of parasitic germs in dog's faeces collected randomly from the public places in urban and rural environments in the Slovak Republic. Out of 578 dog's excrements from public places, 173 were found positive for the presence of the propagative stages of endoparasites, representing the prevalence of $29.9 \%$. In the examined samples, 8 species of intestinal endoparasites were detected. T. canis, T. vulpis and Ancylostomatidae were the major source of contamination. Our results corresponded with those of Antolová et al. (2004), Szabová et al. (2007) and Ondriska et al. (2013) which studied the occurrence of parasites in dogs from Slovakia. Similarly, Neves et al. (2014) monitored the prevalence of gastrointestinal parasites in dogs with no clinical signs from urban area in northern Portugal. Their study reveals a remarkable number of dogs infected but with no clinical signs. The overall prevalence of intestinal parasites (i.e. the presence of at least one species) was $20.6 \%$. Cystoisospora canis was the most prevalent protozoan $(8.0 \%)$ followed by Giardia spp. (7.4\%); T. canis $(5.1 \%)$ was the most frequent helminth, followed by T. vulpis $(1.1 \%)$ and T. leonina $(0.6 \%)$.

Particularly, dogs from the large towns (Košice, Prešov, Zvolen and Trenčín) showed lower prevalence than dogs from smaller towns (Trebišov, Vel'ké Kapušany, Snina, Levoča) and villages (Valaliky, Dlhé Stráže, Dravce). Several factors could influence these differences. In fact, dogs from small towns and rural agglomerations are usually at high risk of infection. It is caused by frequent outdoors activities in gardens or large areas with majority of animals being without preventive care of veterinarians. This is probably also due to free dogs movement in the environment contaminated with faeces from wild animals and consumption of small mammals or wastes from dead and killed wild-boars (Antolová et al., 2006). In rural localities such as Trebišov, Vel'ké Kapušany and Levoča, there are segregated Roma settlements with poor hygiene, bad socioeconomic status and lack of veterinary care for the household animals. The animals from these localities have free movement without restriction and they can contaminate public places with excrements. Problems with uncontrolled and untreated dogs lead to a heavily contaminated environments which under warm climatic conditions could provide good transmission opportunities for zoonotic infections (Won et al., 2008; Lee et al., 2010; Macpherson, 2013). These outcomes are result of depicted cultural and social conditions as well as the lack of fencing and free access to the stray animals.
In urban environment of western Slovakia Ondriska et al. (2013) found in dogs faeces 12 parasite species. In contrast to our study the most frequent parasite was Giardia spp., which occurred at the same rate $(17.8 \%)$ as $T$. canis $(16.5 \%)$. Schär et al. (2014) reported that in rural Cambodia the most frequent parasite found in dogs were hookworms $(80.8 \%)$, followed by the Spirometra spp. (21.3\%) and Strongyloides spp. (14.9\%). Eleven species of parasites (eight helminths and three protozoa) were identified in dogs, seven of which have zoonotic potential (hookworms, Strongyloides spp., Trichuris spp., T. canis, Echinostoma spp., G. duodenalis and Entamoeba spp.).

Among the recovered parasite species in dog's excrements, T. canis and Ancylostomatidae are considered of great public health importance (Lee et al., 2010; Traversa et al., 2010; Riggio et al., 2013). Other parasites (e.g. Trichuris spp., D. caninum) diffusing zoonoses are of minor importance or neglected (Traversa, 2011; Macpherson, 2013; Zanzani et al., 2014). For instance the zoonotic potential of Capillaria aerophila (syn. Eucoleus aerophilus) should also be considered (Lalosevic et al., 2008). Lower level of $T$. leonina in comparison with $T$. canis in dogs might be partially due to the inability of $T$. leonina to reach the offspring via placenta or milk (Traversa, 2012). The results of the present study show that dogs represent a potential risk to the public health. Public places in urban and rural areas pose the main risk of human exposure to the eggs. We are in the agreement with Hotez and Wilkins (2009) and Macpherson (2013) that soil contamination is prevalent in peridomestic environment and exacerbated by poverty, poor hygiene and the risk of contact with infected animals. Actually, it is established that direct contact with infected pets presents no relevant risk in the transmission of intestinal nematodes, and the proportion of pets whose fur is truly contaminated by infectious eggs and the real threat for humans still remains to be elucidated.

Epidemiologically, toxocariasis caused by nematodes $T$. canis and T. cati is considered to be one of the most serious parasitic disease of humans. A crucial factor of $T$. canis infection in human is represented by the ingestion of infective eggs contaminating soil (Fan et al., 2013; Fu et al., 2014; Khademvatan et al., 2014), but also the contact with pets fur contaminated by embryonated eggs should not be ignored (Amaral et al., 2010; El-Tras et al., 2011; Fan et al., 2013; Fu et al., 2014). Toxocara spp. eggs are unembryonated and non-infective when excreted in the faeces of dogs and cats. Eggs can develop to the infective stage within a period of 3 weeks to several months, depending on soil type and environmental conditions such as temperature and humidity (Owergaauw \& Knapen, 2013).

Soil contamination seems to be the most direct indicator of the risk to human populations, mainly in children. Humans became infected usually orally by ingestion of soil with embryonated Toxocara eggs. The high prevalence of canine endoparasites presents a risk factor for dissemination of parasitic propagative stages into the environment. Children population is especially at risk with toxocariasis (Owergaauw \& Knapen, 2013). It is caused by close contact with 
animals, eating sand, grass, soil, small pebbles, faeces, plaster and/or their poor hygiene are at highest risk. The risk of infection is greater in children suffering from geophagy or pica (Papajová et al., 2008; Macpherson, 2013).

This was the reason why we monitored also contamination of sandpits in selected towns in Slovakia. Out of 285 soil samples examined from sandpits in Slovakia 27 were found positive for parasitic germs (eggs from the family Ancylostomatidae, Toxocara spp. and Trichuris spp.). The most frequent were the eggs of Toxocara spp. and their presence was between $4.2 \%$ (Vel'ké Kapušany) and 33.3\% (Valaliky). Animal faeces were not found in any of the sandpits. The higher prevalence of Toxocara spp. in sandpits may be also due stray cats. Cats tend to disperse their faeces around the sandpits, which contributes most to the subsequent contamination. Since the eggs of both Toxocara species are similar in size and morphology, identification based on morphological features by light and scanning microscopy is not conclusive (Borecká, 2004; Khademvatan et al., 2014). Ondriska et al. (2013) found in cats a higher prevalence of toxocariasis than in dogs $(18.6 \%$ respectively $16.5 \%$ ). Overgaauw (1997) found that the presence of $T$. cati in feral cats was $21 \%$ and it is a complicating factor in the prevention of environmental contamination.

Regarding the epidemiology of larval toxocariasis contamination of the environment with Toxocara spp. eggs is a key factor. Some studies showed high contamination of soil in parks, playgrounds, sandpits and other public spaces with eggs of Toxocara spp. (Toparlak et al., 2002; Habluetzel et al., 2003; Matsuo \& Nakashio, 2005; Blaszkowska et al., 2013; Sudhakar et al., 2013). Our results correspond with those of the other authors. In Slovak Republic, Juriš et al. (1991) reported eggs of Toxocara spp. in $18.8 \%$ of sandpits, in faeces and the soil of public areas in Košice. Similarly, Szabová et al. (2007) found Toxocara spp. in $28.3 \%$ examined sand samples from sandpits in Košice. Ondriska et al. (2013) detected Toxocara spp. eggs in $27.0 \%$ of sandpits in Bratislava and in smaller towns in $6.8 \%$ of sandpits. On the contrary, we found higher number of parasite germs in sandpits from smaller towns.

The presence of endoparasites found in dogs excrements and sandpits demonstrates a possible risk of human infection. The implementation of an appropriate control programs towards the reduction of infection in man and animals is recommended (Traversa et al., 2014). Our results indicate the necessity of safe sanitation of municipal wastes from public area with some potential zoonotic agents. One possibility is anaerobic stabilisation in the piles. The effect of anaerobic stabilization of organic wastes from public areas in composting piles in mesophilic and psychrophilic temperature showed that after a 150-day exposure in the pile only $20.11 \pm 1.85 \%$ of $T$. canis eggs were viable (Papajová \& Juriš, 2009).

It is evident, that the occurence of intestinal parasites in dog's excrements pose a source of contamination of the environment in urban and rural ecosystems. In conclusion, intestinal parasites represent a silent hazard not only for other animals, but also for the general public health.

\section{Acknowledgement}

We would like to thank all institutions and people who allowed us to gather data needed for the completion of this study. Special thanks are due to students (Alexandra Czizmárová, Lenka Gáliková, Lucia Kal'amárová, Veronika Lacková and Alexandra Rúčková) for the collection of soil samples and excrements. The study was supported by the Project VEGA No. 2/0140/13.

\section{References}

Amaral, H. L., Rassier, G. L., Pepe, M. S., Gallina, T., Villela, M. M., Nobre Mde, O., Scaini, C. J., Berne, M. E. (2010): Presence of Toxocara canis eggs on the hair of dogs: a risk factor for Visceral Larva Migrans. Vet. Parasitol., 174: 115 - 118. DOI: 10.1016/j.vetpar.2010.07.016 Antolová, D., Reiterová, K., MiterpáKovÁ, M., StanKO, M., DUBINSKÝ, P. (2004): Circulation of Toxocara spp. in suburban and rural ecosystems in the Slovak republic. Vet. Parasitol., 126: 317 - 324. DOI: 10.1016/j.vetpar.20 04.08.005

AntolovÁ, D., ReITERovÁ, K., DubinskÝ, P. (2006): The role of wild boars (Sus scrofa) in circulation of trichinelosis, toxascarosis and ascariosis in the Slovak Republic. Helminthologia, 43: 92 - 97. DOI: 10.2478/s11687-006-0018-9

BlaszKowska, J., WoJcik, A., KuRnatowski, P., SzWABE, K. (2013): Geohelminth egg contamination of children's play areas in the city of Lodz (Poland). Vet. Parasitol., 192: 228 - 233. DOI: 10.1016/j.vetpar.2012.09.033

BoreCKA, A. (2004): Differentiation of Toxocara spp. eggs isolated from the soil by PCR-linked RFLP. Helminthologia, 41: 185 - 187

DESPOMMIER, D. (2003): Toxocariasis: Clinical aspects, epidemiology, medical ecology, and molecular aspects. Clin. Microbiol. Rev., 16: 265 - 272, DOI: 10.1128/ CMR.16.2.265-272.2003

El-Tras, W. F., Holt, H. R., TAYEL, A. A. (2011): Risk of Toxocara canis eggs in stray and domestic dog hair in Egypt. Vet. Parasitol., 178: 319 - 323. DOI: 10.1016/ j.vetpar.2010.12.051

FAn, C. K., LiaO, C. W., ChenG, Y. C. (2013): Factors affecting disease manifestation of toxocarosis in humans: genetics and environment. Vet. Parasitol., 193: 342 - 352. DOI: 10.1016/j.vetpar.2012.12.030

Fu, Ch. J., Chuang, T. W., Lin, H. S., Wu, Ch. H., LiU, Y. Ch, Langinlur, M. K., Min-Yun Lu, M. Y., HsiaO, W. W.W, FAN, CH. K. (2014): Seroepidemiology of Toxocara canis infection among primary schoolchildren in the capital area of the Republic of the Marshall Islands. BMC Infect. Dis., 14: 261. DOI: 10.1186/1471-2334-14-261

Habluetzel, A., Traldi, G., Ruggieri, S., Attili, A. R., Scuppa, P., Marchetti, R., Menghini, G., Esposito, F. (2003): An estimation of Toxocara canis prevalence in dogs, environmental egg contamination and risk of human infection in the Marche region of Italy. Vet. Parasitol., 113: 243 - 252. DOI: 10.1016/S0304-4017(03)00082-7

Hotez, P. J., WiLkins, P. P. (2009): Toxocariasis: Ameri- 
ca's most common neglected infection of poverty and a helminthiasis of global importance? PLoS Negl. Trop. Dis., 3: e400. DOI: 10.1371/journal.pntd.0000400

JuRIŠ, P., PlachÝ, P., DuBINSKÝ, P. (1991): Hygienic problems of dog breeding in urban habitats, with a focus on Toxocara spp. In Ecology and veterinary medicine, pp. 24

KAZACOS, K. R. (1983): Improved method for recovering ascarid and other helminth eggs from soil associated with epizootics and during survey studies. Am. J. Vet. Res., 44: $896-900$

Khademvatan, S., AbDizadeh, R., Tavalla, M. (2014): Molecular characterization of Toxocara spp. from soil of public areas in Ahvaz southwestern Iran. Acta trop., 135: 50 - 54. DOI: 10.1016/j.actatropica.2014.03.016

KinČEKovÁ, J., ReITEROVÁ, K., DuBInSKÝ, P. (1998): Relapse of the manifest course of larval toxocarosis in childhood. Helminthologia, 35: $21-26$

KinČEKOVÁ, J., ReITEROVÁ, K., DubinskÝ, P. (1999): Larval toxocariasis and its clinical manifestation in childhood in the Slovak Republic. J. Helminthol., 73: 323 - 328 KinČEKOVÁ, J., REITEROVÁ, K., JuHÁs, T. (2000): Complications of ocular larval toxocarosis in 5-year-old child and their surgical treatment. Helminthologia, 37: $19-21$

Lalosević, D, Lalosević, V., Klem, I., StanojeVJovanović, D., PoziO, E. (2008): Pulmonary capillariasis miming bronchial carcinoma. Am. J. Trop. Med. Hyg., 78: $14-16$

Lee, A. C., Schantz, P. M., Kazacos, K. R., Montgomery, S. P., Bowman, D. D. (2010): Epidemiologic and zoonotic aspects of ascarid infections in dogs and cats. Trends Parasitol., 26: 155 - 161. DOI: 10.1016/j.pt.2010.01.002.

MACPHERSON, C. N. L. (2013): The epidemiology and public health importance of toxocariasis: A zoonosis of global importance. Int. J. Parasitol., 43: 999 - 1008. DOI: 10.1016/j.ijpara.2013.07.004

Matsuo, J., NAKashio, S. (2005): Prevalence of fecal contamination in sandpits in public parks in Sapporo City, Japan. Vet. Parasitol., 128: 115 - 119. DOI: 10.1016/ j.vetpar.2004.11.008

Neves, D., Lobo, L., Simoes, P. B., Cardoso, L. (2014): Frequency of intestinal parasites in pet dogs from an urban area (Greater Oporto, northern Portugal). Vet. Parasitol., 200: 295 - 298. DOI: 10.1016/j.vetpar.2013.11.005.

Oge, S., OGe, H. (2000): Prevalence of Toxocara spp. eggs in the soil of public parks in Ankara, Turkey. Dtsch. Tieraerztl. Wochenschr., 107: $72-75$

Ondriska, F., MAČUHOVÁ, K., MElicherovÁ, J., Reiterová, K., VAlentová, D., BeladičovÁ, V., HALGOŠ, J. (2013): Toxocariasis in urban environment of western Slovakia. Helminthologia, 50: 261 - 268. DOI 10.2478/s11687-013-0139-x

Overgaauw, P. A. M. (1997): Prevalence of intestinal nematodes of dogs and cats in Netherlands. Vet. Quart, 19: 14 - 17. DOI: 10.1080/01652176.1997.9694730

Overgaauw, P. A. M., KNAPEN, F. (2013): Veterinary and public health aspects of Toxocara spp. Vet. Parasitol., 193: 398 - 403. DOI: 10.1016/j.vetpar.2012.12.035
Papajová, I., Juriš, P., Szabová, E., VenglovskÝ, J., SAsÁKOVÁ, N., ŠEFČíKOVÁ, H., MARTinez, J., GÁBOŇ, T. (2008): Decontamination by anaerobic stabilisation of the environment contaminated with enteronematode eggs Toxocara canis and Ascaris suum. Biores. Techn., 99: 4966 4971. DOI: 10.1016/j.biortech.2007.09.044

PAPAJOVÁ, I., JURIŠ, P. (2009): The effect of composting on the survival of parasitic germs. In: PEREIRA, J. C., Bolin, J. L. (Eds) Composting: Processing, Materials and Approaches. New York: Nova Science Publishers, pp. 124 $-171$

PAPAJOVÁ, I., JURIŠ, P. (2012): The sanitation of animal waste using anaerobic stabilisation. In: KUMAR, S., BHARTI, A. (Eds) Management of organic waste. Rijeka: InTech, pp. $49-68$

Riggio, F., Mannella, R., Ariti, G., Perrucci, S. (2013): Intestinal and lung parasites in owned dogs and cats from central Italy. Vet. Parasitol., 193: 78-84. DOI: 10.1016/j.vetpar.2012.11.026

Ruiz de Ybánẽz, M. R., Garijo, M. M., Alonso, F. D. (2001): Prevalence and viability of eggs of Toxocara spp. and Toxascaris leonina in public parks in eastern Spain. $J$. Helminthol., 75: 169 - 173. DOI: 10.1079/JOH200164

Schär, F., InPANKaEW, T., Traub, R. J., KhIEU, V., DAlsGaArd, A., Chimnoi, W., ChHoun, Ch., Sok, D., Marti, H., Muth, S., OdermatT, P. (2014): The prevalence and diversity of intestinal parasitic infections in humans and domestic animals in a rural Cambodian village. Parasitol. Int., 63: 597 - 603. DOI: 10.1016/j.parint.2014.03.007

SZABOVÁ, E., Juriš, P., MiterPÁKOVÁ, M., ANTOlOVÁ, D., PAPAJOVÁ, I., ŠEFČíKOVÁ, H. (2007): Prevalence of important zoonotic parasites in dog populations from the Slovak Republic. Helminthologia, 44: 170 - 176. DOI: 10.2478/s11687-007-0027-3

Statistical YeARBoOK of the SLOVAK RePUBLIC 2013. VEDA, Bratislava, 2013

Sudhakar, N. R., Samanta, S., Sahu, S., Raina, O. K., Gupta, S. C., Madhu, D. N., Kumar, A. (2013): Prevalence of Toxocara species eggs in soil samples of public health importance in and around Bareilly, Uttar Pradesh, India. Vet. World., 6: 87 - 90. DOI: 10.5455/vetworld.20 13.87-90

Toparlak, M., Gargili, A., TüYer, E., Keles, V., Ulutas Esatgil., M., Cetinkaya, H. (2002): Contamination of children's playground sandpits with Toxocara eggs in Istanbul, Turkey. Turk. J. Vet. Anim. Sci., 26: 317 - 320

Traversa, D., Di Cesare, A., Conboy, G. (2010): Canine and feline cardiopulmonary parasitic nematodes in Europe: emerging and underestimated. Parasit. Vectors, 3. DOI: 10.1186/1756-3305-3-62

TRAVERSA, D. (2011): Are we paying too much attention to cardio-pulmonary nematodes and neglecting old-fashioned worms like Trichuris vulpis? Parasit. Vectors, 4. DOI: 10.1186/1756-3305-4-32

TRAVERSA, D. (2012): Pet roundworms and hookworms: A continuing need for global worming. Parasit. Vectors, 5. DOI: $10.1186 / 1756-3305-5-91$

Traversa, D., Frangipane di Regalbono, A., Di Cesare, 
A., La Torre, F., Drake, J., Pietrobelli, M. (2014): Environmental contamination by canine geohelminths. Parasit. Vectors, 7: 67. DOI: 10.1186/1756-3305-7-67

Won, K. Y., Kruszon-Moran, D., Schantz, P. M., JONES, J. L. (2008): National seroprevalence and risk factors for zoonotic Toxocara spp. infection. Am. J. Trop. Med. Hyg., 79: 552 - 557

RECEIVED JULY 31, 2014
Zanzani, S. A., Gazzonis, A. L., Scarpa, P., Berrilli, F., MANFREDI, M. T. (2014): Intestinal parasites of owned dogs and cats from Metropolitan and Micropolitan Areas: Prevalence, zoonotic risks, and pet owner awareness in Northern Italy. Biomed Res. Int., 2014. DOI: 10.1155/20 $14 / 696508$

ACCEPTED SEPTEMBER 30, 2014 